\title{
Discursive Australia: Refugees, Australianness, and the Australian Public Sphere ${ }^{1}$
}

\author{
Jane Mummery \& Debbie Rodan
}

[W] e decide who comes to this country and the circumstances in which they come.

(Prime Minister John Howard, Campaign Launch, 21 Oct. 2001, Sydney)

\section{Introduction}

The discussion within Australia of events of the last five years, such as 9/11, the Bali Bombing, the Tampa and the Children Overboard affair, the Cronulla Riots, as well as the numbers of refugees approaching Australian shores, has typically fallen into a binarized form with public discourses coalescing around calls for either 'protectivism' or 'humanitarianism' (Mummery \& Rodan, 2003). This discursive framework has in turn instantiated an ongoing debate concerning the issue of what it means to be Australian, and who is or should be included or excluded from this national identity, questions which have been particularly contentious in recent years. ${ }^{2}$ This project, however, aims to unpack and analyse just one manifestation of this debate, that carried out in letters to the editor published between 22 January and 28 February 2002 in both The Australian ${ }^{3}$ (Australia's national daily broadsheet) and The West Australian (Western Australia's daily broadsheet). The period chosen for this analysis is important for several reasons. First, given that it encompasses the Woomera Detention

Jane Mummery is a lecturer in philosophy at the University of Ballarat. She is the author of The Post to Come: an Outline of Post metaphysical Ethics (2005), and her current research turns around the ethico political possibilities and implications of contemporary European philosophy. Her most recent work is published in Philosophy Today and Symposium.

Debbie Rodan lectures in the Media \& Cultural Studies stream at Edith Cowan University. She has previously published on social and cultural identity formation. Current research projects include: examining the recurring discourses within the letters to the editor and how they underpin and ratify certain notions of being 'Australian'; and an analysis of the ways in which ethnic Hazara refugees from Afghanistan have been (re)presented in two Australian television programmes. Correspondence to: Debbie Rodan, Media and Cultural Studies Department, Edith Cowan University, 2 Bradford Street, Mount Lawley, WA 6050, Australia. E mail: d.rodan@ecu.edu.au 
Centre hunger strikes, an examination of letters written during this period clearly shows the mixture of responses many Australians feel towards Australia's policies with regard to the detaining and processing of refugees and the issue of their eventual release into the Australian community. More specifically, we suggest that these letters have foregrounded - and perhaps even ratified—clearly binarized attitudes as to what being Australian—or indeed being un-Australian—does and should mean. Finally, we consider some of the broader implications of this debate, suggesting that this kind of binarized framing of it would seem to easily promote divisiveness and wedge politics, where communities are divided into seemingly heterogeneous sections. ${ }^{4}$ Such an outcome, however, has a tendency of closing debate down in favour of name-calling and other vilification. Given this, we suggest reframing the dichotomy of contrasting identities as set out in the letters, in terms of the more nuanced relations made possible through the concept of what we call, following Chantal Mouffe and Stuart Hall, 'articulation'. Such a move could have long-lasting implications for how we understand our communities and social life.

\section{Context}

Before we begin our analysis, however, there are a number of points that require some initial clarification. These concern the general role and responsibility of the media, the more specific role of letters to the editor, the way these letters shore up particular notions of Australian national identity, and, finally, our basic approach and methodology. With regards to the first of these points, many media theorists, media analysts and politicians in Australia would see the role and responsibility of the media as being much more than simply meeting market demand and, thereby, media users as more than consumers (Raboy et al., 2001; Jacka, 2000; Schultz, 1994). The media are thus seen as playing a social role-that is, as having a responsibility to audience members as national citizens, voters, members of a public sphere, and so on. As such, there seems to be, as Norman Fairclough puts it, a 'complex dialectic' existing 'between the media and the conversational discourse of everyday life' (1995, p. 64). A point also made by the Anti-discrimination Board of New South Wales' report Race for the Headlines: Racism and Media Discourse. This report, in remarking upon the currency of 'anti-Arabic and anti-Muslim sentiment' (McCausland, 2003, p. 68), suggests that this attitude is fuelled both by current and past political rhetoric about ethnicity and crime etc., and the ways in which media commentators disseminate such rhetoric. Race for the Headlines indeed points to a long history in Australia of political and media commentators legitimating the association between ethnicity and crime, arguing that as a consequence they have 'manipulate[d]' fear of the ethnic 'other' (pp. 68-69). And this means that we can agree with Fairclough when he suggests that we can usefully examine media discourse as a 'domain of cultural power and hegemony' (p. 67). In a similar vein, Wanning Sun (2005, p. 82) writes that the print media can instil in diverse individuals 'the confidence that whatever they are doing 
(or reading, watching, or listening) is shared anonymously by the rest of the population'. That is, it can instil a sense of community.

In this way it seems clear that letters to the editor do represent instances of public debate, albeit in a limited form, and that they additionally represent sites for the development of public opinion. As Karin Wahl-Jorgensen notes in her analyses of the role of letters to the editor, many letters editors see this section as a 'wide open public forum' (Wahl-Jorgensen, 2002a, p. 130). Although it is clear that this belief is unrealistic, given first the role of letters editors in selecting and editing letters for publication and second the fact that letter writers tend not to be representative of the general population, ${ }^{5}$ Wahl-Jorgensen nonetheless concludes that letters to the editor are 'conducive to the creation of social solidarity' (2001, p. 304). They are, in other words, conducive to the creation of both public opinion and a sense of identity, in this case of Australianness. For instance, as Ryfe has noted, letter writers tend to assume 'the voice of the collective "we", seeing themselves as speaking 'for me and for everyone else' (Ryfe, 2001, p. 777). Hence, in writing on behalf of all 'Australians', 'patriots', 'fellow human beings', etc., letter writers not only assume that their views are embodiments of public opinion-an assumption that is, of course, partially borne out by the tendency of the print media to publish letters that are already representative of perceived common themes-but in effect legitimate certain discourses as proper to the public discussion of current events. In other words, despite the very real constraints preventing us from seeing letters to the editor either as a simple reflection of public opinion or as indicative of the sort of unmediated public debate desired by Habermas, ${ }^{6}$ it is by the very foregrounding of certain discourses within these published letters (each asserting or supporting a collectivity) that these discourses can be normalized, to at least some extent, within the public domain.

Finally, mention should be made of our approach and methodology. To begin with, as should be clear by now, we are not simply engaged in a micro-level practice of applied linguistics or content analysis. Rather, we are concerned with developing here what we call, following McHoul and Fairclough, a critical discourse analysis. More generally, discourse theory offers a useful set of concepts and approaches for the analysis of social constructions and interactions. Viewing society as a contingent construct in which social identities and relations are able to be temporarily fixed and disseminated, discourse theory presents discourse as 'whatever constrains-but also enables_writing, speaking, and thinking within ... specific historical limits' (McHoul, 1994, p. 944). Such an approach thus allows us to explore some of the specific ways in which 'social objects'-in this case, those of refugees and Australianness-have been spoken, written and thought about at a specific point in history. ${ }^{7}$ After all, as Fairclough et al. put it, we 'organize and act through particular discourses' in so far as discourses can 'simultaneously sustain, legitimize, and change' our ways of acting and organizing (Fairclough et al., 2004, p. 2). In other words, it allows us to argue for the interrelation of discourses being utilized in the public domain and social attitudes, an interrelation that thereby registers the 'discourse-led character of social change' $(2004$, p. 2). 
Lastly, we do need to stress again that although we are arguing that the debate, as exemplified in the letters to the editor, instantiates and ratifies the discrete public discourses that we have previously called 'protectivism' and 'humanitarianism', these discourses are in no way individually homogeneous. They each incorporate a range of different threads and values that may be only loosely interrelated. Additionally, as we will show, they both interact around the notions of what it means to be Australian and un-Australian.

\section{Protectivism: Keeping Them Out, They're Un-Australian ${ }^{8}$}

They forced their way in here then made demands and held a gun to our heads and we are supposed to welcome them with open arms. No way ... Get rid of them and put a stop to this madness. (Butler, 29 Jan. 2002 WA $)^{9}$

This type of protectivist discourse has become increasingly common since 11 September and President George Bush's ensuing Address to the Nation where he made a clear distinction between 'us' (civilized) and 'them' (barbaric), further contending that 'if you're not with us, then you're against us. ${ }^{10}$ In this view 'they' mark a threat that is simply too great to be borne, whether 'they' come in the form of terrorists, Muslims or refugees-particularly given that within Australia these categories have also tended to be conflated by this discourse. Letter writers using this discourse consequently call for the threat to be removed: 'Send them back' (Hollitt, 31 Jan. 2002 WA; cf. Young, 1 Feb. 2002 WA); 'Remove the lot of them' (Hanley, 29 Jan. 2002 WA). Indeed, for this discursive position, 'keeping these people out of our civilized and beautiful country' (Campbell, 28 Jan. 2002 WA) is a priority.

Overall, then, within post-Tampa Australia the 'they' has come to mean 'illegal immigrants' who are also 'criminals' (e.g. Campbell, 28 Jan. 2002 WA). They are 'not like us'. They have a 'belligerent attitude' (Edwards, 28 Feb. 2002 WA), engage in appalling and 'inappropriate behaviour' which inspires in us a 'deep repugnance' (Koehne, 24 Jan. 2002 A). Indeed, they demonstrate a 'total lack of humanity' (Ford, 2 Feb. 2002 WA), and represent a 'danger to Australia' (Christy, 24 Jan. 2002 A):

[S] urely all Australians would not want these people wandering around in our community. Do we really want these desperate kinds of acts to be part of our culture when someone cannot get what they want? (Davidson, 22 Jan. 2002 WA)

The main point that seems to underpin this discourse, then, is that the 'they' have no possible place in our community. Further, we are unable to envision that they might ever 'fit in' to our community, believing rather that 'they won't and/or can't integrate'.

Now there are, of course, a number of ways we could further unpack this discourse of protectivism. However, what we want to focus on here is how this discourse is deployed to underpin a very specific notion of what it means to be Australian. Basically, for this discourse, being Australian entails abiding by a particular set of values, values which, it is also worth noting, have tended to be framed here in negative terms - that is, being Australian means not being or doing certain things. In other words, we affirm 
what it is to be Australian by recognizing what it is to be un-Australian. For instance, being Australian means fitting in to the wider Australian community-it means not establishing oneself in a separate cultural enclave (Marsh, 22 Jul. 2004 WA). Being Australian also means abiding by Australian laws and common practices. More specifically, it means not 'stoning and subjugat[ing] women, [practising] genital mutilation and hangings' (Catchatoor, 2 Feb. 2002 WA). It is further linked to not wantonly destroying property or one's documentation, not rioting, not engaging in acts of self-mutilation, and not trying to force the government's hand or hold it to ransom (e.g. Cohen, 29 Jan. 2002 A). Finally, being Australian entails definitely not engaging in any acts of child abuse (Mann, 24 Jan. 2002 WA).

To sum up, then, it seems that being un-Australian, as far as it is instantiated through this protectivist discourse, is to commit actions and practices that are seen to be themselves intrinsically un-Australian: 'Anyone who does that to their child is not only unfit as a parent but also unfit to be an Aussie' (Radford, 22 Jan. 2001 WA), and

$[\mathrm{W}]$ ill they renounce their misogyny, arranged marriages, genital mutilation, religious intolerance and extreme interpretations of female modesty? I think not. Such practices are endemic in their culture and have endured for centuries. (Norgaard, 5 Feb. 2002 WA)

\section{Humanitarianism: Being Australian Means Giving Everyone a 'Fair Go'}

To those protesting the actions of the asylum seekers at Woomera: What situation would you have to find yourself in, to sew up your mouth, swallow poison or use your children as political tools? I'd imagine it'd have to be pretty dire. Perhaps you shouldn't be so quick to judge these people until you've walked a mile in their shoes. (Grant, 24 Jan. 2002 A)

In contrast to the previous discursive position, that coalescing around an ideal of 'humanitarianism' is not premised on the exclusive and divisive (see Evans 19 Oct. 2001 A; cf. Ruddock, 27 Sept. 2001 A; Morgan, 15 Feb. 2002 A) logic of 'us' versus 'them', but on an inclusive logic emphasizing the common identity of being human, of shared humanity. ${ }^{11}$ This is also at the base of a recognition of obligation and responsibility. In this case, 'we' (the Australian nation) are delineated as having an obligation both individually and as a nation toward asylum seekers (DeAngelis, 12 Feb. 2002 A; Everingham, 7 Feb. 2002 A).

For this reason, letter writers with this view claim that 'we' have a duty and responsibility to 'shelter' refugees simply because they are 'fellow human beings' (Mills, 30 Jan. 2002 A; Taskis, 5 Feb. 2002 A; Inglis, 1 Feb. 2002 WA; Rogers, 30 Jan. 2002 WA). Such an attitude also results in a very different view of refugees. Actions that were read in the previous discourse as criminal or unsavoury-or, indeed, as unAustralian-are here read as demonstrating 'desperation', 'distress' and 'frustration' (e.g. Byrne \& White, 1 Feb. 2002 WA; Ainsley, 2 Feb. 2002 WA; Tonkinson, 26-27 Jan. 2002 A). These actions are performed by people who are at their 'wits' end' and at 'breaking point' (Hill, 24 Jan. 2002 WA; Hoffman, 30 Jan. 2002 A). Such actions 
'indicate the extremity of their personal darkness' and 'anguish' (Farran \& Curnow, 29 Jan. 2002 A). Furthermore, they are understandable in so far as 'denied any voice, they only have their bodies to communicate their utter desperation' (Hoffman, 30 Jan. 2002 A):

If your national response is to incarcerate, demoralize and remove hope and any capacity for independence of action, then primitive behaviours of despair, rage and envy emerge. (Tonge, 29 Jan. 2002 A)

The events at Woomera are creating a tribal psyche that has no sense of hope and is beginning to decay from despair. (Farran \& Curnow, 29 Jan. 2002 A)

Now what we see here, then, is an interesting reversal in perspective from that of the previous discourse. Whereas proponents of protectivism are concerned primarily with 'them' and their actions-and how they don't conform to our required standard-those promoting humanitarianism have focused their concern on 'us' and our actions. This reversal is particularly interesting when we consider the issue of Australianness. Basically, proponents of humanitarian discourse bring the markers of Australianness to bear on those who already claim that identity. In other words, far from 'them' being 'unfit to be an Aussie' (Radford, 22 Jan. 2001 WA), 'we' are being un-Australian in treating 'vulnerable, scared and traumatized people with contempt' (Groessler, 29 Jan. 2002 A), where being un-Australian means being inhumane (Supple, 11 Feb. 2002 A; Humberston, 29 Jan. 2002 WA; Warren, 23 Feb. 2002 WA), unchristian (Hyde, 4 Feb. 2002 A; O’Leary, 8 Feb. 2002 A; Ainsley, 2 Feb. 2002 WA; Geoghegan, 14 Feb. 2002 A) and racist (Timcke, 11 Feb. 2002 A). As one letter puts it: 'It is we who are really mutilated, not the detainees' (Farran \& Curnow, 29 Jan. 2002 A). And another:

It's getting to the stage where I am ashamed to be called an Australian when so many of my own countrymen $[s i c]$ hold the view that this is the right way to treat refugees. (Ainsley, 2 Feb. $2002 \mathrm{WA}$ )

To put this in positive terms, then, being Australian means giving people a 'fair go', the 'benefit of the doubt' (Groessler, 29 Jan. 2002 A), and giving them the chance to 'live' in and 'contribute to [a free] society' (White, 1 Feb. 2002 WA). These, then, are the very markers of Australianness that proponents of this sort of discourse suggest that we are not displaying.

Finally, given that this discursive position critiques the performance of our unAustralianness at the institutional (political) as well as the individual level, we now need to look at the way in which certain tenets of both of these discourses have seemed to further instantiate and ratify an overarching discourse of divisiveness and wedge politics. That is, we need to consider the interaction of these two discursive positions.

\section{The Discourse of Divisiveness}

To begin with, even a brief consideration of the letters published in this period shows a strong trend towards the establishing and maintaining of clear divisions not only 
between the refugees and the broader Australian community but also between proponents of each of these major discourses. Indeed, any debate between proponents of these disparate discourses seems to lead inexorably into name-calling. Although the letters editor for The Australian intervened in late 2001 (30 Nov. 2001 A) in letters discussing the Tampa refugees, stating that "reverse abuse" will not be a continuing theme on the Letters page', name-calling has nonetheless been quite consistent throughout this later period of letters.

For instance, it is very clear that for letter writers drawing on the tenets of humanitarian discourses, anyone (other letter writers, the government and/or critics of the refugees) who is not prepared to show compassion (Reynolds, 22 Jan. 2002 WA) or even simple humanity to refugees is 'mean, nasty and selfish' (Cariss, 2 Feb. 2002 WA; Emery, 1 Feb. 2002 WA), and 'shallow and callous' (Young, 31 Jan. 2002 WA), not to mention un-Australian. Humanitarian letter writers are 'ashamed of recent events' (Hughes-d'Aeth, 18 Feb. 2002 WA), 'ashamed of our country's position' (Pryor, 1 Feb. 2002 A), and appalled at how the Australian people can be so easily 'moved to irrational hatred against a group of fellow human beings' (Hughes-d'Aeth, 18 Feb. 2002 WA). Overall, they see the federal government's policies about mandatory detention as 'misguided' (Cannon, 24 Jan. 2002 A), 'harsh' (Tonkinson, 26-27 Jan. 2002 A), racist (Ryan, 26-27 Jan. 2002 A; Slater, 29 Jan. 2002 A; Tranter, 12 Feb. 2002 A; Reynolds, 22 Jan. 2002 WA; Ondaatje, 20 Feb. 2002 WA), and 'unconscionable' (Anderson, 2-3 Feb. 2002 A). Most basically they are appalled at how these policies have been used first to 'foster public anger towards a group of people for electoral benefit' and second to 'rationalise evil' (Kan, 2-3 Feb. 2002 A; Gill, 13 Feb. 2002 WA).

For such proponents of the humanitarian discourse, then, these attitudes to refugees not only result in a 'climate of unease and fear' (Belfield, 18 Feb. 2002 WA) but also a prevailing and far-reaching discourse of divisiveness that can be seen to be entrenched in a number of ways. First, as we have already discussed, we have that very basic distinction being sustained between 'us' (civilized Australians) and 'them' (barbaric refugees), ${ }^{12}$ a division that has resulted in Australia's policies and practices concerning refugees being described as demonizing and 'dehumanising' (e.g. Fazel, 14 Feb. 2002 A). In addition, we have a grossly observable division being entrenched between proponents of each of the two main discursive positions. Here, proponents of humanitarian discourses clash with those of protectivist discourses over such issues as how we should treat refugees, how we should see those key institutions directly concerned with the treatment of refugees, and, of course, just what it means to be Australian. This division, as we have already shown here (also see Mummery \& Rodan, 2003), has been maintained in particular through a process of ongoing name-calling. For instance, those holding to the other discursive position are called bleeding hearts, the chattering classes, racists, xenophobic, stony hearts and so forth: 'I would rather be known as having a "bleeding heart" than a "stony heart" (Morgan, 5 Feb. 2002 WA).

As noted, this divisiveness is also carried on to respective attitudes towards those institutions involved in Australia's treatment of refugees. For supporters of a humanitarian discursive position, these institutions have been tarnished. For instance, 
the federal government is called upon to move out of the 'political sewer', 'regain some national respectability' (Reynolds, 18 Feb. 2002 WA), and 'to conduct our debate in a morally constructive way that will lead to honorable solutions' (Date, 4 Feb. 2002 $W A)$. As another letter writer puts it:

Apart from the effect on the refugees themselves, the saddest aspect of this whole sordid affair of vilification of asylum seekers is what it has done to the integrity of our defense and security services and our federal public service. These institutional icons have been irreparably damaged. (Argy, 15 Feb. 2002 A; cf. Anderson, 23 Feb. 2002 A)

In contrast, supporters of a protectivist discourse see these same institutions and their policies as reflecting 'the "court of public opinion"' (Gamble, 31 Jan. 2002 WA), and as carrying out the will of the Australian public. They are in fact representatives of the 'voice of reason' (Robinson, 31 Jan. 2001 A). As one letter writer puts it:

John Howard's Government was overwhelmingly elected on a policy of firm action where illegal immigrants were concerned. Any backdown by Immigration Minister Philip Ruddock would amount to a gross betrayal of the Australian electorate. (Lea, 29 Jan. 2002 WA; cf. Campbell, 28 Jan. 2002 WA)

Furthermore, those calling for a 'backdown' by the government are described in ways that represent them to be naïve, a 'soft-touch' (Cohen, 29 Jan. 2002 A), if not irrelevant: they are 'sideline commentators' who have had the 'great luxury of never actually having to make the hard [read "real"] decisions' (Cameron, 26-27 Jan. 2002 A).

Overall, then, it seems apparent that on these and other issues, and through a process reminiscent of wedge politics, these contrasting discursive positions are being viewed by their respective proponents as irreconcilable, suggesting in addition that these discursive positions mark heterogeneous sections of the community. It would thus seem that this discourse and practice of divisiveness is becoming entrenched within this domain, and also perhaps within Australian society, although this latter claim is, of course, a problematic one.

\section{Problems and Possibilities}

Political parties are constantly criticized for not allowing their members to dissent publicly from party policy. However, whenever a genuine debate occurs within any party as in the current Labor Party about its policy on asylum seekers all the media immediately talk, or write about, 'split', 'schism' or 'infighting'. Why do they not report that there is a healthy debate about policy? Until they do so, they will hinder the development of the vigorous, open debate that our political system needs. (Hutchison, 12 Feb. 2002 A)

There are, of course, several points to be considered in this section. Certainly, any argument suggesting a causal link between what is expressed in letters to the editor and the actual state of society is highly problematic. As we have already noted, it is simply not possible to make this sort of link for any number of reasons. Nonetheless, we do contend, along with Fairclough et al., that one way to better understand social life 
(and change) is to examine the discourses that, for one reason or another, have become entrenched in the public domain.

Turning, then, to our foregoing analysis, we are concerned at the ease with which debate in the public domain has tended to close down into name-calling, the reification and reiteration of fixed identity claims ('us', 'them', Australian, un-Australian), and the accompanying reliance on wedge politics and its associated practice of divisivenesspractices that show no signs of dissipating. We believe that it is becoming increasingly important to challenge this all-too-easy recourse to a discourse of divisiveness, and those practices that close debate down rather than open it up. Now there is, of course, no easy solution to this tendency, no matter how we unpack the debates being played out in the public domain. However, one possibility here, we suggest, is to shift the frame of our debate on refugees and Australianness from divisiveness to what has come to be called 'articulation'.

Now this, as flagged above, has become a key term in discourse theory. Given that discourse theory marks and stresses the acceptance of contingency with regards to the social domain, 'articulation' is defined as 'any practice establishing a relation among elements such that their identity is modified as a result' (Laclau \& Mouffe, 2001, p. 105). More precisely, to speak of articulation is to speak of the contingency of what it is to point to the possibility of 'other ways of theorising the elements of a social formation' (Slack, 1996, p. 117). Articulation, in other words, refers to the practice and form of any connection so as to reveal its inherent contradictions and alternative constructions. As Mouffe puts it, articulation is the reminder that all social constructions and identities are the result of no more than the establishing and negotiating of contingent equivalences and common concerns. In Hall's words:

An articulation is thus the form of the connection that can make a unity of two different elements, under certain conditions. It is a linkage which is not necessary, determined, absolute and essential for all time. You have to ask, under what circumstances can a connection be forged or made? So the so called 'unity' of a discourse is really the articulation of different, distinct elements which can be rearticulated in different ways because they have no necessary 'belongingness'. The 'unity' which matters is a linkage between the articulated discourse and the social forces with which it can, under certain historical conditions, but need not necessarily, be connected. Thus, a theory of articulation is both a way of understanding how ideological elements come, under certain conditions, to cohere together within a discourse, and a way of asking how they do or do not become articulated, at specific conjunctures, to certain political subjects. (Hall, 1996, p. 141 142)

When this understanding of social objects and identities is applied to the binaried public discourses prevalent in the debate carried out in these letters, what is immediately highlighted is the possibility of moving from the compulsive reiteration of difference (between, for instance, respective proponents of protectivism and humanitarianism, as well as between refugees and the Australian community), to an affirmation of practices and possibilities of relation and connection. It is the possibility, in other words, of realizing that we are able to do things differently. 
Different practices, for instance, might not assume and desire sameness or full assimilation as such, but might rather promote the development and recognition of equivalences and common concerns across different groups. Now this, if accepted, would not only provide the basis for continuously transformative negotiation and dialogue, but would, in the long run, also support the idea of a community being not so much an existent thing but a doing. Such practices could, in other words, sustain the pluralism of a highly provisional and contingent 'we'. This would be a 'we' that, having recognized its own contingent character, would be cautious in arguing too far or fast from claims of identity, inclusivity or exclusivity.

This possibility and proposal is not new, of course, and is in fact to be found throughout the letters we examined. In amongst the prevailing tendency towards closing debate down and name-calling-tendencies we see as indicative of a reliance on processes of division and exclusion-we have a call for a 'vigorous, open debate' (Hutchison, 12 Feb. 2002 A). We have a call to 'allow [the refugees] into the community so that we can communicate with them, hear their stories and start thinking of them as people. [And so that] [m] aybe then some of the people who don't want them may learn to understand them' (Silvester, 28 Jan. 2002 WA). It is a call, in other words, to move beyond the reification of differences. It does not demand the immediate rejection of difference, but suggests dialogue and negotiation as the basis for recognizing possible equivalences, these being the basis for any community. Indeed, the 'people of Dubbo' are held up by several letter writers as exemplifying such a possibility because of their welcoming of refugees into their community. That is, they can be seen as instituting their community not through any presupposed sense of its makeup but through what we could describe as practices of articulating disparate elements and, in so doing, transforming them.

Overall, then, this is a proposal for a change in how we perceive our social relations with others. More specifically, it is a reminder that we can always reassess what we had taken to be either common sense or the way things are, a reminder that we are never able to say 'how it is, so it will always be so' (Hall, 1996, p. 142). It is a proposal to move from the publicly entrenched 'us versus them' binary-whether it's the binary of the Australian community versus refugees, or that between the proponents of protectivism versus those of humanitarianism-to the possibility of a loosely articulated 'we' engaged in dialogue and negotiation, engaged indeed in what Mouffe would argue is the very basis for any democratic community. (She argues that pluralism and its character of conflict are not only constitutive of the political but vital resources for actual democracy) (Mouffe, 1993, p. 6). Hence, a democratic community, as Mouffe sees it, is neither the result of rational communicative debate among disinterested citizens who have reached consensus as John Rawls (1993) suggests, nor is it the result of shared norms as Habermas (1984) suggests. Nor is it the top-down instantiation argued for by many letter writers, where we are part of a community (or civilized, or moral, or democratic, etc.) because of who we are, while you are not because of who you are. Rather, as Laclau and Mouffe put it, 'the experience of democracy should consist of the recognition of the multiplicity of social 
logics along with the necessity of their articulation', the latter of which needs to be 'constantly re-created and renegotiated' (Laclau \& Mouffe, 2001, p. 188). Consequently, a community (even that of a nation) is very far from having any clear-cut identity or even clear-cut borders. The 'we' of any community is instead necessarily provisional and partial — the outcome of a relating or articulating with no inherent or ideal selfness or identity. Community is hence nothing more and nothing less than the result of the negotiations that emerge from the bottom up, and are lived, experienced and articulated in the everyday by already interested and involved people. Far from being an abstract ideal, community results from the doing of those transformative negotiations which exemplify the democratic process. It is, as Mouffe stresses elsewhere, a form of life that is only instantiated by the doing of it. ${ }^{13}$ Further, to misquote Mouffe, realizing the 'we' of any community entails also realizing the impossibility of ever fully realizing any community. ${ }^{14}$

This is also a proposal for a change in how we might more fruitfully consider apparently irreconcilable discourses in the public sphere, where debate is unlikely to be settled via recourse to either abstract ideals or even rational argumentation. ${ }^{15}$ After all, as should be clear from the preceding analysis, these letter writers are affirming disparate discourses ${ }^{16}$ in highly passionate ways, ways that tend to result in the wholesale dismissal of contrasting discourses. When, however, we look to the doing of articulation-in this case, the possible articulation of the different discourses regarding refugees and Australianness - we recognize that difference need not end in divisiveness. Far from seeing divisive conflict as the end of discussion or negotiation, or indeed as rigidifying community (or indeed national) boundaries, Mouffe's work reminds us that these conflicts can be reframed. To best overcome divisiveness, we, and our community, can perhaps begin with moving to a practice of articulation.

\section{Notes}

[1] Earlier versions of this paper were presented at the 2004 Annual Conference of the Centre for Research on Social Inclusion: Mobile Boundaries Rigid Worlds, Sydney, Australia; and the 2004 Cultural Studies Association of Australia Conference: Everyday Transformations: The Twenty first Century Quotidian, Perth, Australia.

[2] For example, the results of a major survey carried out in Australia just after $9 / 11$ showed that Muslims and people from the Middle East were considered by the broader population to be unable to fit into Australian culture and society, that they were too different (Dunn \& Mahtani, 2001, pp. 63 72). A similar view was also remarked upon by Race Discrimination Commissioner Bill Jonas who was reported in The West Australian (4 Dec. 2001) as being 'struck by the level of discrimination against Australians who did not fit the national stereotype'. The latest manifestation of this view is the debate on Australian values that was instituted in the aftermath of the Cronulla Riots and Prime Minister John Howard's reflective speech on national identity, delivered to the National Press Club on Australia Day 2006. Recent papers addressing the debate include those by Perera (2002) and Turner (2003).

[3] News Limited owns The Australian. There are twelve daily newspapers and two national newspapers in Australia News Limited owns over half and Fairfax owns a quarter (Australian Financial Review as well as the state newspapers Sydney Morning Herald and The Age in 
Melbourne). Kerry Stokes owns The West Australian. There is little diversity in ownership of the Australian newspaper press.

[4] Shaun Wilson and Nick Turnbull define 'wedge politics' as a 'calculated political tactic aimed at using divisive social issues to gain political support, weaken opponents and strengthen control over the political agenda' (2001, p. 3). Steve Mickler illustrates the way in which this works in his analyses of talkback radio. He argues that talkback radio was 'ideally suited to the "wedge politics" that the Howard government deployed (specifically utilizing a 'racial or ethnic wedge') both prior to and for the duration of the 1998 and 2001 federal elections (Mickler, 2004, p. 100).

[5] In investigating the extent to which letter writers are representative of the general population, most research has found that letter writers tend to be 'white, middle aged and well educated males who are firmly situated in a community and have the excess time and energy required for a commitment to political activism' (Wahl Jorgensen, 2002b, p. 77; cf. Sparks \& Perez, 1991). In addition to this constraint, Wahl Jorgensen also contends that letters are selected by letters editors on the basis of four rules: 'relevance, entertainment, brevity, and authority' (2002b, p. 70). The selection of letters, then, is based on both content and form, with their needing to be well written, grammatically correct, and persuasive. Through this selection process, then, letter writers who want to be published learn to present well written, strong and unambiguous positions, with the resultant letters delivering passionately held beliefs containing no doubts as to the letter writer's standpoint. In Judith Elen's (letters editor for The Australian in 2001) words, letters need to be 'about one issue ... as short as possible, straight to the point ... passionate ... but informed and the information correct' (The Media Report, 12 Jul. 2001). For a detailed discussion of editorial policy concerning letters to the editor, see Karin Wahl Jorgensen (2001, 2002b).

[6] We mean here Habermas's desire for a domain for public debate (and information gathering) that is free from explicit interference, whether by government, business or other interests. Given that these letters (and letter writers), in many cases, passionately defend a highly specific 'way of life', it is certainly problematic to see them as part of a rational 'open debate' by disinterested and independent citizens (Webster, 1995, p. 103; Habermans, 1992). Conversely, given that letter writers do tend to declare their own positions up front one of the main criteria for information that is useful for this domain/debate it is still possible to argue that letters can deliver pertinent information to the Habermasian public sphere.

[7] This approach of utilizing discourse theory has become increasingly popular. Chantal Mouffe, for instance, is concerned to clarify the overall democratic project this way $(1993,2000)$. Turning to more specific projects, Stuart Hall (1998) has applied discourse theory to the immigration debate in the United Kingdom. See also Sutherland (2005).

[8] From our analysis of the two newspapers over the same period (22 January 28 February 2002) we observed a slight difference with regard to letter content in each. By and large, in the West Australian letters section there was greater support for the government policy regarding detention of refugees that is a stronger thread of the protectivism discourse. The Australian letters section, however, tended to have a more evenly balanced number of letters in terms of each discourse.

[9] All letter extracts are from letters published in the letters to the editor sections in either The West Australian (WA) or The Australian (A) on the date given.

[10] For our discussion of this distinction, please see Mummery and Rodan (2003).

[11] It must be noted, however, that the premise which informs this position of globalized humanitarianism the notion that we all share an 'essential' humanity also marks it as problematic. That is, this premise asserts a form of cultural relativism. To put it another way, with its essential foundation being our shared humanness, cultural identity is construed as something which is layered over the top, as opposed to something one is born into and which is inextricably linked with being human. 
[12] It is worth noting that this division was also seen to be maintained through a deliberate policy of refusing the media, and other independent observers, access to the refugees in detention centres. As one letter writer puts it, we have been 'kept in the dark' (Deeth, 30 Jan. 2002 A): 'Let the media in. Let the truth be known and let the refugees be heard' (Hoffman, 30 Jan. 2002 A; cf. Deeth, 30 Jan. 2002 A; Davidson, 1 Feb. 2002 A).

[13] Mouffe discusses the democratic process in terms of the Wittgensteinian 'forms of life' in The Democratic Paradox (2000).

[14] Mouffe actually writes, 'radical democracy also means the radical impossibility of a fully realized democracy' (1992, p. 14), but, as we have suggested above, her discussion of radical democracy can usefully be transcribed into a discussion of the notion and nature of community.

[15] As Debbie Rodan writes: 'agreement between cultures is more likely to be reached through negotiation and compromise than through a process of rational argumentation' (2004, p. 67).

[16] Interestingly, we could argue that our distinction between protectivist and humanitarian discourses represents a distinction that Mouffe draws between the differing traditions of democracy and liberalism. Proponents of a protectivist discourse would be firm adherents to democratic principles, while letter writers who claim, just as passionately, the need to see refugees as 'people like us' and who promote humanitarian practices are clearly drawing on the principles of liberalism. For Mouffe's discussion of this distinction, see The Democratic Paradox (2000).

\section{References}

Dunn, K. M. \& Mahtani, M. (2001) 'Media representations of ethnic minorities', Progress in Planning, vol. 55, no. 3, pp. 6372.

Elen, J. (2001) 'Letters to the editor; e rights', The Media Report, 12 Jul., Available at: http://www.abc. net.au/rn/talks/8.30/mediarpt/index/MediaReportChronoIdx.html.

Fairclough, N. (1995) Media Discourse, Edward Arnold, London and New York.

Fairclough, N., Graham, P., Lenke, J. \& Wodak, R. (2004) 'Introduction', Critical Discourse Studies, vol. 1 , no. 1 , pp. 17 .

Habermas, J. (1984) 'The Theory of Communicative Action', vol. 1. Reason and the Rationalization of Society, trans. T. McCarthy, Beacon Press, Boston.

Habermas, J. (1992) 'Further reflections on the public sphere', in Habermas and the Public Sphere, ed. C. Calhoun, MIT Press, Cambridge, MA, pp. 421461.

Hall, S. (1996) 'On postmodernism and articulation: an interview with Stuart Hall', in Stuart Hall: Critical Dialogues in Cultural Studies, eds L. Grossberg, D. Morley \& K. H. Chen, Routledge, London and New York, pp. 112127.

Hall, S. (1998) 'The rediscovery of "Ideology"', in Literary Theory: an Anthology, eds J. Rivkin \& M. Ryan, Blackwell, London, pp. 10501064.

Howard, J. (2006) 'John Howard's Australia Day address to the National Press Club', 25 Jan., Available at: http://www.australianpolitics.com/news/2006/01/06 0125 howard.shtml

Jacka, E. (2000) 'Public service TV: an endangered species?', in The Australian TV Book, eds G. Turner \& S. Cunningham, Allen \& Unwin, St Leonards, pp. 5268.

Laclau, E. \& Mouffe, C. (2001) Hegemony and Socialist Strategy: Towards a Radical Democratic Politics, Verso, London and New York.

McCausland, R. (2003) Race for the Headlines: Racism and Media Discourse, Anti discrimination Board of New South Wales, New South Wales.

McHoul, A. (1994) 'Discourse', in The Encyclopaedia of Language and Linguistics, vol. 2, eds R. E. Asher \& J. M. Simpson, Pergamon Press, Oxford, pp. 940949. 
Mickler, S. (2004) 'Talkback radio, anti-elitism and moral decline', in Us and Them: Anti-elitism in Australia, eds M. Sawer \& B. Hindess, API Network, Australia Research Institute, Perth, pp. $97-116$.

Mouffe, C. (1992) Dimensions of Radical Democracy, Verso, London and New York.

Mouffe, C. (1993) The Return of the Political, Verso, London and New York.

Mouffe, C. (2000) The Democratic Paradox, Verso, London and New York.

Mummery, J. \& Rodan, D. (2003) 'Discourses of democracy in the aftermath of $9 / 11$ and other events: protectivism versus humanitarianism', Continuum: Journal of Media \& Cultural Studies, vol. 17, no. 4, pp. 433-443.

Perera, S. (2002) 'The Tampa, boat stories and the border: a line in the sea', Cultural Studies Review, vol. 8 , no. 1 , pp. $11-27$.

Raboy, M., Abramson, B. D., Proulx, S. \& Welters, R. (2001) 'Media policy, audiences, and social demand: research at the interface of policy studies and audience studies', Television \& New Media, vol. 2, no. 2, pp. 95-115.

Rawls, J. (1993) Political Liberalism, Columbia University Press, New York.

Rodan, D. (2004) Identity and Justice: Conflicts, Contradictions and Contingencies, Peter Lang, Brussels.

Ryfe, D. (2001) 'From media audience to media public: a study of letters written in reaction to FDR's fireside chats', Media, Culture \& Society, vol. 23, no. 6, pp. 767-781.

Schultz, J. (1994) 'Media convergence and the fourth estate', in Not Just Another Business: Journalists, Citizens and the Media, ed. J. Schultz, Pluto Press, Leichhardt, pp. 15-33.

Slack, J. D. (1996) 'The theory and method of articulation', in Stuart Hall: Critical Dialogues in Cultural Studies, eds D. Morley \& K. -H Chen, Routledge, London and New York, pp. 112-127.

Sparks, M. K. \& Perez, E. (1991) 'Women not heard in letters columns', The Masthead, vol. 43, no. 2, pp. $14-15$.

Sun, W. (2005) 'Media and the Chinese diaspora: community, consumption, and transnational imagination', Journal of Chinese Overseas, vol. 1, no. 1, pp. 65-86.

Sutherland, C. (2005) 'Nation-building through discourse theory', Nations and Nationalism, vol. 11, no. 2, pp. 185-202.

Turner, G. (2003) 'After hybridity: Muslim Australians and the imagined community', Continuum: Journal of Media \& Cultural Studies, vol. 17, no. 4, pp. 411-418.

Wahl-Jorgensen, K. (2001) 'Letters to the editor as a forum for public deliberation: modes of publicity and democratic debate', Critical Studies in Media Communication, vol. 18, no. 3, pp. 303-320.

Wahl-Jorgensen, K. (2002a) 'The normative-economic justification for public discourse: letters to the editor as a “wide open” forum', Journalism \& Mass Communication Quarterly, vol. 79, no. 1, pp. $121-133$.

Wahl-Jorgensen, K. (2002b) 'Understanding the conditions for public discourse: four rules for selecting letters to the editor', Journalism Studies, vol. 3, no. 1, pp. 69-81.

Webster, F. (1995) Theories of the Information Society, Routledge, London.

Wilson, S. \& Turnbull, N. (2001) 'Wedge politics and welfare reform in Australia', Australian Journal of Politics and History, vol. 47, no. 3, pp. 1-23. 